\title{
The Effect of Problem Solving Learning Models on Students' Understanding of Physics Concepts
}

\author{
*Apriani Sijabat, Herna Febrianty Sianipar, Theresia Monika Siahaan, Osco P. Sijabat \\ Physcis Education Department, Faculty of Teacher Training and Education, \\ University Of HKBP Nommensen Pematangsiantar,Sangnaualuh No.4, Pematangsiantar, \\ 21132, Indonesia
}

*Corresponding Author e-mail: aprianisijabat@gmail.com Received: June 2021; Revised: June 2021; Published: June 2021

\begin{abstract}
The goal of this study is to see how problem-solving learning paradigms affect students' grasp of physics ideas. This study is a quasi-experimental study. The sample was chosen using the cluster random class methodology, which consisted of two classes, the first of which was taught using a problem-solving learning model and the second of which was taught using traditional methods. Experiment classes provide problem-solving opportunities to help students better understand physics ideas, while control classes are taught in a traditional manner. Pre- and post-test results from students in both classes were used to collect data. The two-way Anavatest was applied, and the level of significance was found to be 0.000 (sig. 0.05), indicating that problem solving learning is beneficial in improving students' understanding of physics concepts.
\end{abstract}

Keywords: Problem Solving; Students' Understanding; Physics concepts

How to Cite: Sijabat, A., Sianipar, H., Siahaan, T., \& Sijabat, O. (2021). The Effect of Problem Solving Learning Models on Students' Understanding of Physics Concepts. Prisma Sains : Jurnal Pengkajian Ilmu dan Pembelajaran Matematika dan IPA IKIP Mataram, 9(1), 52-56. doi:https://doi.org/10.33394/j-ps.v9i1.3858

https://doi.org/10.33394/j-ps.v9i1.3858

Copyright $\odot$ 2021, Sijabat et al This is an open-access article under the CC-BY License.

\section{INTRODUCTION}

The Basic Concept of Science is one of the compulsory courses for PGSD teacher candidates at the Faculty of Teacher Training and Education, University of HKBP Nommensen Pematangsiantar. The Science Basic Concepts course is given in the first semester because it is a prerequisite course for the following courses in the following semester. One of the materials contained in the Science Basic Concepts course is about Simple Electricity, which is a physics learning material. Based on observations in the field, the teaching and learning process in the classroom tends to be analytical with an emphasis on deriving physics formulas through mathematical analysis. Students try to memorize formulas but they do not have any meaning for what and how they are used. Moreover, in the PGSD study program where students who enter the PGSD department are from the Social Studies and Language majors while in high school so that students do not understand science material, while the basic science concept course is a compulsory subject. Lecture and question and answer methods are methods commonly used by lecturers in the order of explaining, giving examples, asking questions, practicing, and giving assignments.

The questions emphasize mathematical manipulation so that students who are less capable in mathematics will find it difficult to learn physics and the questions that are trained are very far from the real world of students so that learning Basic Science Concepts becomes less meaningful for the students themselves. Many students are able to present a good level of memorization but cannot understand the concept (Alacac,2010). The results of preliminary observations of the condition of PGSD students who were studying the Basic Concepts of Science subject showed that most students were not yet ready to accept learning. This is 
indicated by students' indifference and lack of enthusiasm in learning, especially in providing complete learning tools (books and lecture materials). They also act passively considering that the basic concepts of science have a lot to do with physics. Most of the students are weak in their mastery of concepts and calculations. This condition is supported by a statement expressed by previous research that the level of understanding of students' concepts is still very low(Issi,2015). Not only students in school, the problem of understanding the concept of physics also occurs in university students as explained by (Supriyadi, 2003). The low understanding of these concepts is a natural thing where the facts in the field show that the learning process that occurs is still conventional and centered on lecturers and students is only passive, there is less response in the form of questions or arguments or asking for reexplanations, students are more often only given ready formulas. use without understanding the meaning of the formulas (Rojas,2010). Mastery of good concepts as something meaningful, because it is actually more than just memorizing, which requires the willingness of students to seek a conceptual relationship between the knowledge they have and what is being learned in the classroom. Meaningful learning means, in addition to the material presented must be adapted to the students' abilities, it must also be relevant to the student's cognitive structure, so that the material must be related to the concepts (knowledge) that students already have and be linked to other fields or daily life The learning process like this will be more meaningful so that the basic concepts of this science will not be lost quickly. (Slameto, 2003) states that conceptual understanding is the ability of students to interpret science scientifically both in theory and in its application. Concept understanding is a person's ability to understand or understand something after something is known and remembered. In other words, understanding is knowing about something and being able to see it in many ways. Comprehension is a level of thinking ability which is one level higher than memory and memorization. A concept is an idea or ideas that are generalized from human experience with some object events and facts (Sujarwata,2009) stated that learning is more teacher centered, making students not involved in discussing and asking many things using their thinking patterns, but not more than just listening to and memorizing the concept of the material being taught, this fact causes student understanding and mastery of concepts,as an indicator of learning success, it is generally not satisfactory( Rawzis,2015). To solve this problem, we need a solution in the learning process in order to improve the ability to understand physics concepts. One of the learning models suitable for use in physics learning is the defender model. The novelty in this research is in accordance with the government program that launched the independent campus program, the problem solving learning model also follows the independent campus program where the problem solving model emphasizes students to be able to solve problems and is required to be more active (student center).

\section{METHOD}

This study took place in January 2019/2020 academic year at FKIP PGSD University HKBP Nommensen Pematang Siantar semester I. All PGSD students in semester I of HKBP Nommensen Pematang Siantar University for the 2019/2020 academic year were included in this study. The study's sample was divided into two classes at random, the experimental class and the control class, comprising 40 students with the identical starting ability level. The experimental class is taught using the Problem Solving learning paradigm, whereas the control class is taught using traditional learning techniques. The sampling method was straightforward and random (simple random class). This research employed a quasiexperimental approach (Sudjana,2009). Quasi-experimental research employs a large number of subjects in a natural experiment that occurs in the classroom, but does not control all of the factors. The goal of this study is to see how the independent and dependent variables interact.This study involved two classes, namely the experimental class and the control class 
who were given different treatments. This study featured two groups, the experimental and control groups, each of which received different treatments.

\section{RESULTS AND DISCUSSION}

The results of the research that will be presented are the understanding of students' physics concepts in the basic concepts of science learning in the P5 PGSD UHKBPNP group. Students' understanding of physics concepts is one of the factors that can affect student success as measured by a concept understanding test instrument before learning is carried out. The results of this study will be described starting from the pretest data acquisition of the basic science concept results of each class, the results of the acquisition of the conceptual understanding test for each class, as well as the results of student posttests for each class. Understanding the concept in this study is a moderator variable which is considered not influenced by the learning process, meaning that it is the attitude that students have in dealing with problems related to physics. Therefore the instrument was given before the learning activity took place to group students based on understanding the concept.

Table 1. Average Score of Pretest and Posttest

\begin{tabular}{ccc}
\hline \multirow{2}{*}{ Class } & \multicolumn{2}{c}{ Test } \\
\cline { 2 - 3 } & Pretest & Postest \\
\hline Control & 21.7 & 65 \\
Eksperiment & 21.8 & 77 \\
\hline
\end{tabular}

According to the table, both the control and experiment classes improved their problem-solving skills after receiving treatment. However, the average improvement of the eksperiment class is greater than that of the control class. It demonstrates that problemsolving-based learning is more successful than traditional learning. Problem solving skills improvement analysis can be seen and categorized based on gain score as shown on Table

Table 2. Average Gains Score

\begin{tabular}{ccc}
\hline \multirow{2}{*}{ Class } & \multicolumn{2}{c}{ Score } \\
\cline { 2 - 3 } & Gain & Category \\
\hline Control & 0.52 & Medium \\
Eksperiment & 0.74 & High \\
\hline
\end{tabular}

In this study, the gain score of the experiment class is higher than the gain score of the control class. According to table 2, students' problem-solving skills increase at a medium rate in the control class but at a high rate in the experiment class. The two-way Anava test is used to examine hypotheses in this study. Condition of parametric statistic testing on anava-test had been through normality and homogeneity. Result of homogeneity test is show in Table 3 . Table 3. Test of Homogenity of Variances

\begin{tabular}{llllll}
\hline & Levene & & & & \\
\cline { 2 - 6 } & Statistic & Df1 & Df2 & sig \\
\hline Pretest Score & 0.377 & 3 & & 80 & .769 \\
\hline
\end{tabular}

Homogeneity test is being held to see if problem solving skills of control and experiment class variance based on Levene Statistic are homogenous or not. According to homogeneity test in table 3 showed that significance (sig.) are higher than 0.05 (0.769 $>0.05$ ). It shows that control and experiment class distribution are homogenous.

According to normality and homogeneity test results, it shows that data is distributed normally and homogenous. Data that distributed normally and homogenous can be tested using Two-way anava test. Two-way anava test is served in Table 4. 
Table 4. Two-way Anava test

\begin{tabular}{lcccc}
\hline \multirow{2}{*}{ Varians source } & Df & Mean Differences & F & Sig. \\
\cline { 2 - 5 } corrected model & 3 & 1372.719 & 13.228 & .000 \\
corrected not model & 1 & & & \\
\hline
\end{tabular}

According to the table, the results of the two-way Anava test can be used to determine whether $\mathrm{H} 0$ will be accepted or refused. The sig value of the two-way anava test is.000, as can be seen. Because the value of sig. 0.0000 .05 is less than 0.05, H0 is rejected and Ha is accepted. It means that adopting the problem-solving learning paradigm to master physics ideas in a fundamental science concepts course is superior than traditional learning.

\section{CONCLUSION}

Based on the outcomes of the data analysis and discussion, it can be concluded that learning about the core concept of ipa is useful in improving students' problem-solving skills. This conclusion is based on the fact that the experimental class average score gain is higher than the control class average score in the high category. Communicating in both written and spoken form, organizing the experiment, forecasting the hypothesis, interpreting the observation, observing, measuring, and using tools and materials were all part of the learning process. Aside from that, learning through problem solving is easier to recall and can help students develop their problem-solving skills as well as their understanding of physics concepts.

\section{RECOMMENDATION}

For further researchers to pay attention to the use of time in using problem solving models, and further researchers can develop problem solving models for other physics materials

\section{ACKNOWLEDGMENT}

The author would like to appreciation to the Institute for Research and Community Service (LPPM) University Of HKBP Nommensen Pematangsiantar who has supported this research, it can be carried out well and all participant who support and help to completed this article.

\section{REFERENCES}

Alacac, C. (2010). Solving A Stability Problem By Polya's Four Steps, International Jourrnal Of Electronics Mechanical And Mechatronics Engineering. 1(1), 19-28.

Issi, A. (2015). Pemecahan Masalah Dinamika Partikel Melalui Strategi Problem Solving Conflict Map Untuk Meningkatkan Konseptual siswa. Jurnal Pendidikan Fisika

Rawzis, K. (2015). Penerapan Model Pembelajaran Fisika Berorientasi problem Solving Untuk Meningkatkan Hasil belajar Ranah kognitif Dan Kemampuan Pemecahan Masalah Pada Materi Suhu dan Kalor. Jurnal Pendidikan Fisika

Rojas. S. (2010). On the Teaching and Learning of Physics Problem Solving. Revista Mexicana De Fisica 56 (1) 22-28

Sardiman, A.M. (2008). Interaksi dan Motivasi Belajar Mengajar. Jakarta: Raja Grafindo Persada.

Slameto. (2003). Belajar dan Faktor-Faktor yang Mempengaruhinya. Jakarta: Rineka Cipta

Sudjana, N. (2000). Penilaian Proses Dan Hasil Belajar. Bandung : PT. Remaja Rosdakarya.

Sujarwata. (2009). Peningkatan Hasil Belajar Elektronika Dasar II Melalui Pembelajaran Model Problem Solving Laboratory. Jurnal pendidikan Fisika Indonesia 
Supriyadi. (2003). Fisika dan Konsep Sains Terpakai Dalam Konteks Kompetensi Model Pembelajaran dan Portofolio. Yogyakarta: Tempel Sari Books Company Media Group. 